\title{
Mixing at sudanese universities and its effects on students' psychological and social compatibility, academic achievement and innovation
}

\author{
Mohammed Othman Al-Mihaisi* \\ Um Durman University, Department of Psychology, College of Education, Najran University, Saudi Arabia
}

\begin{abstract}
The present study was concerned with the problem of mixing at Sudanese universities and its relationship with students' psychological and social compatibility, academic achievement and innovation. The descriptive analytical approach was used. None of the well-known psychological scales was used as the present study was completely abstract and theoretical. It concluded that most of the Sudanese universities are mixed, and most students suffer from academic problems of different levels as well well as problems of psychological and social compatibility. The review of many studies and researches conducted in the academic surrounding proved that whenever male students are separated from female ones, success and innovation outcome of both genders was greater. Furthermore, the proportion of attention, cognition and psychological compatibility increased significantly when these two genders are separated. At the end, the present study put forward some recommendations and proposals that would help mixed Sudanese universities and communities to overcome their academic, educational and psychological hardships in order to be more effective, adaptable and happier.
\end{abstract}

\section{Introduction}

Nowadays, the topic of young people has been one of the important issues to which educationists, psychologists, sociologists, and health scientists pay much attention. Developed countries are even interested in the young because they believe that the nation's progress is based on their potentials. They also believe that nations live and progress strongly by the power of those individuals who work to discover, develop, and utilize the physical resources and consequently harness them in the service of economic, social and cultural development plans.

Young adulthood is one of the important and sensitive stages of the human life because of the changes and growth that he/she passes through. Therefore, it is not surprising that studies regarding this stage are many [1] believe that the young entering the university is somewhat new experience that is different from his previous ones. The idea of the university, argues Ball et al. as cited in [1] is based on the assembling of students and professors of all disciplines at one institute or one university for the sake of broadening understanding and assisting in understanding mutual values.

There is no doubt that young people entering into the world of university community raises strongly the problems of compatibility and interaction with such community. It is a kind of arbitrariness to separate youth compatibility problems from their problems of growth and change in the community where they live [2] pointed out that compatibility is an adaptive relationship with the environment, which includes the individual's ability to meet his needs and most of the social and physiological requirements. University is actually a small community where a student lives, which plays a major role in his life as it prepares him for productive job, helps him to grow physiologically, psychologically and socially. According to [3] many views and notes indicate that students at university face sharply compatibility where relations at university are impersonal and where large groups of students do not interact deeply and continually nor taking into account the circumstances of all people. Therefore, students' compatibility with their university environment requires them to adjust their methods, strategies and skills for the sake of success and achievement.

The review of social compatibility theories reveals that compatibility was considered of different angles [4]. For example, the theory of psychoanalysis believes that compatibility occurs through satisfying the needs and learning how to deal with ones' internal conflicts. The social learning theory expresses normal compatibility through the individual's skill to interact successfully with his environment. The humanitarian theory, on the other part interprets compatibility according to the individuals' trends of growth as an ongoing process, whereas, cognitivist and behaviorism do not defined compatibility directly. The first believes that compatibility means thinking logically, while the latest believes that behavior is only the function of the normal education. Some people have interpreted compatibility as a process that satisfies the psychological and social needs. The individual does not guarantee organizing the satisfaction of his needs, but he may be exposed to a conflict between these needs. In this case, his compatibility issues arise and he finds himself obliged to solve this conflict and learn how to face the situations where his needs grapple whenever he is subjected to such situations. The conflict of psychological needs arises if the satisfaction of one need opposes the satisfaction of another one

Correspondence to: Mohammed Othman Al-Mihaisi, Um Durman University, Department of Psychology, College of Education, Najran University, Saudi Arabia, E-mail: mehassco@hotmail.com

Received: October 10, 2016; Accepted: October 26, 2016; Published: November 28,2016 
because the satisfaction of the first need frustrates the second need.

To illustrate the process of psychological compatibility [5] elaborates on compatibility as a behavioral process that leads to adjustment and as an achievement or accomplishment.

\section{First, compatibility as a behavioral process that leads to adjustment}

The individual, while moving towards the achievement of compatibility, exhibits a certain behavior by which he confronts his internal and external needs and overcomes the conflict between these needs if arises. The behavioral process he performs to meet these needs and their conflict is the process that enables him to achieve the psychological compatibility at the end.

\section{Second, compatibility as an achievement or accomplishment}

Compatibility can be learned. That is, the individual at childhood learns certain ways to respond to specific situations. His compatibility is the result of such learning. Therefore, if he learns proper ways, he will have goods compatibility. Nevertheless, bad compatibility results if he learns bad ways.

Scientists were much concerned with social interaction between individuals, which is the core of compatibility. They, as Kert Levin, considered are the basis for the group. They also pointed out that an amendment results from this interaction, which occurs when two persons or more communicate (not necessary physically). Perhaps, it is important to note that social interaction processes include cooperation, competition, and conflict [1]. Radwan [6] believes that social interaction is the most important element in social relations and so the culture where the individual and group live is colored by the social interaction [7] argues that we will be more precise if we take into our account the concept of sociocultural interaction [3] mention that there are three trends in the interpretation of human personality formulation (compatible and non-compatible):

- Anthropological trend that gives specific importance to civilization in determining the individual's values and motives.

- Genetic trend, which emphasizes the importance of genetic predisposition in determining the individual's behavior.

- Interactive socio-cultural trend supposing that developing the human personality is done through forming relationships with others, through the interaction between the individual and himself, on one hand and the existing social institutions, which operate in a particular cultural setting, on the other hand. Hence, it is difficult to study the phenomenon of university students' adaptation in isolation from their interaction with the university atmosphere where they study.

Al-Zayyadi [8] confirms that the academic success of college students involves the ability to establish fruitful social relationships with others, the ability to adapt to the effective productive work, and the investment of personal energies to sufficiently make the individual useful in his social surroundings [9] corroborates this view while defining compatibility with university community. He pointed to the level of university student satisfaction regarding the social relationships, the psychological and academic elements, and the control factors which he is exposed to within university frame.

In conclusion, it is important to study university students' compatibility through understanding the context of their interaction with the socio-cultural context of university. The study of college student problems of compatibility will not be meaningful unless the university socio- cultural atmosphere is studied. Therefore, the present study tries to analyze and clarify some of the students' attitudes towards mixing and its relationship with their psychological, social and academic compatibility. It also aims to understand the effect of mixing on their academic achievement. The topic has been chosen in such a way because mixing may affect negatively a college student's compatibility and consequently his academic achievement, which may lead to stagnation in his innovation. Furthermore, positive psychological, social and academic compatibility can empower a student to form good and satisfying relationships with his friends and teachers in the field of academic study and university life. In addition, success in social relations will increase the success of social interaction and enables the student to reach a high degree of overall compatibility.

\section{Aims of the study}

The present study aims to highlight some of the attitudes of students at Sudanese universities toward mixing and its relationship with some psychological, educational, social, academic variables; academic achievement and innovation. It also aims to identify the relationship of their academic problems with their psychological, social and academic compatibility. In addition, it seeks to demonstrate the relationship of the psychological, social and academic compatibility with students; academic achievement and whether mixing affects it or not. The study also tries to identify the differences between males and females regarding their psychological, social and academic compatibility. Eventually, the study aims to draw conclusions, recommendations and proposals that could overcome the obstacles of students in Sudanese universities and help them cope successfully with the difficulties they meet and pave the way for them to be innovators and happy students happy.

\section{Statement of the problem}

When a student enrolls in a Sudanese university, he finds himself in an environment where there are many new elements. He finds himself in a new place, which is strange and unfamiliar for him. He has come to this new place from a place where he was living among his family members. At university, he is far away from his home and family. $\mathrm{He}$ has left the family atmosphere, entered a noisy community, and joined a large number of people whom he does not know at all. Within this new atmosphere, he does not master the appropriate ways of conduct. He faces this new environment with many implicit questions, various concerns, and a variety of perceptions of different frameworks. In addition, he suffers from a number of crises caused by his growth, study, thinking of his future, and his position in his present. He might overcome all these troubles and crises. He even might have difficulties in solving some or most of them. Some students at mixed Sudanese universities suffer from a lot of anxiety and conflicts. Some of them pass while others fail. Some of them succeed in overcoming anxiety and conflicts. A university student passes through this sensitive period of his life in the stage of sexual maturation that may secrete different conflicts. He holds a number of sediment from the past that have begun since earlier periods and have gradually gained formulas during the past years. Nevertheless, this does not mean that the student will not face a new circumstance. His sexual motive is stronger; externalities that accompany maturation of this motive make it difficult to be hidden by males and females. The control of students' community is severe as well as their feeling. Neural sensitivity that typically accompanies this phenomenon becomes a strain among anxiety factors, in addition to what is also shown by the society such as threat or reprimand 
tendencies in front tendencies where the sex motive is strong. Sexual maturity might be accompanied by many difficulties for a university student. He feels the ability and desire, but he is deprived of potentials, sometimes led by frustration while searching for a way out, which might be the resistance, prudence, foresight, adherence to true religion. Resistance might be weak. Sayings of some people about the merits or demerits of mixing such as love or corruption might reach him and increase his anxiety and complexity.

Hefny [10] points to another area related to college student's social life. He says that during this period, the student becomes more reflective than before due to his internal sense and astonishment of its forms. Reflection sometimes drives him to compare his body and power with the bodies and powers of others. Such comparison leads him to the sense of inferiority or bravado. Both cases cause him to escape, which make him authoritarian on those who are weaker than him for the sake of getting back his self-respect, or they make him under the control of those who are superior to him. As a result, his study and relations with peers and colleagues will be definitely affected by such sense. Such cases may lead to deterioration in student's compatibility level and achievement. However, other students may take their decisions, fortify their wills and be capable of bypassing these conflicts and difficulties successfully.

In fact, university demands quite a little effort from students in order to pursue study in a number of subjects that sometimes need contact and sometimes have spacing. The effort is necessary for success at college and transition from class to another. However, sometimes a student faces particularly a difficult course that sometimes changes into a problem. Sometimes a student fails to reach the required level of achievement that satisfies university in most courses. His failure might be affected by many reasons such as his potential, frequent absences, relations with university peers, or mixing and involvement in many issues outside university. Therefore, he finds himself facing hard difficulties that increase his anxiety and crisis. He, for instance, might be obliged to repeat the year in the same class and face the problems of frustration. He might have to change the university and bear difficulties regarding frustration, on one part and compatibility with the new environment on the other part. He even might be forced to change the type of study.

All mentioned above are just thoughts, observations and views about students' situations at Sudanese mixed universities that have attracted the researcher's attention and put him in the confrontation of a real educational and psychological problem. In fact, he felt this problem when he saw the failure of some of his relatives, acquaintances, and friends at some mixed Sudanese universities. It also became greater when he and his colleagues noticed the low academic level of their students at various universities, in addition to students' weakness to academically go along with their peers.

Thus, the researcher, in order to understand the nature and forms of mixing problem, he decided to undertake the present study to find out the problems of these students and their relevance to some psychological and educational variables to arrive at a set of proposals that would alleviate these problems.

\section{Importance of the study}

Psychological, social and academic compatibility is an important factor in the educational process. Psychological, social and academic problem-free student may lead to the creation of a balanced personality parallel with educational values to which the educational process aims
[11] believes that psychological and social compatibility is one of the most important elements that help the formation of normal life among the growing humans to achieve their proper adjustment with their environment and society. Therefore, the present study is important because it aims to detect the academic problems related to the process of mixing and the causes that may lead to poor psychological, social, and academical compatibility of university students, besides its importance in the educational and social environment.

Thus, this research alongside its scientific importance has a practical importance and realistic need because the research population is big and increasing rapidly. The students' psychological, social and academic compatibility is the direct responsibility of their families as well as educational institutions, which should include the movement of scientific research.

At the end, the present study concludes a set of results and recommendations that will contribute to the treatment of problems associated with the educational process so that education movement in Sudan will not lose considerable numbers of its people. Parents, on the other part, can enjoy their children psychological compatibility and relief. Whereas, the homeland will get what it desires from achievement.

\section{What is mixing?}

Mixing, in general, is a fertile ground for the occurrence of many behavioral and psychological deviations. It drags the human being on these two levels and, at a specific time, he finds himself lost all his psychological means of defense that stand in the face of Satan and devil self. He also falls under Satan's dreaded authority and away from Godly mercy. Such mixed spaces are really of the easy targets that Satan and his soldiers aim at. They use all their weapons, mesmerize, trappings and illusions, so that they can seduce the human being, "Satan said: 'My Lord, for your perverting me, I shall make matters in the earth seem most fair to them and I shall pervert all, except the devoted amongst your worshippers", (Holy Koran, Sourat Al-Hijr, verses 39-40). For this reason, mixing has a particular danger that imposes on man the knowledge of the legitimate boundaries that prevent him from falling into the trap of the devil and his soldiers. Such knowledge assures adequate protection and immunity for man to remain dear in this world and be a winner in the afterlife.

Mixing means that both men and women mingle together. The meeting between women and men who are foreigners for each other in one place, usually results in meeting each other, one part look at the other, or a conversation between them. To understand whether mixing is allowed or taboo, we need to understand whether the woman is like a man regarding mixing with a foreign man. That is, is the woman's mixing with a foreign man as the mixing of a man with a foreign man without any differences? The answer is definitely no. Nobody mentioned that she is like the man when mixing with a foreign man. Therefore, it can be said that her mixing with a foreign man is not allowed. It is taboo because she and the man are not alike.

\section{When mixing is allowed}

Mixing is allowed for the legitimate necessity, need, or habit in these cases:

1. Mixing for necessity

2. Mixing for need that includes mixing to:

a) conduct legitimate transactions, 
b) carry out judiciary business,

c) get a certificate,

d) carry out business calculation,

e) serve guests,

f) entertain guests and greet them by eating with them,

g) use public transportation,

h) carry out acts of Jihad,

i) listen to preaching and guidance, and

j) practice it as a habit [12].

\section{Beginnings of mixing in education}

Mixing, according to the Islamic Nation Network started in the educational institutes and universities in Islamic countries for nearly a century. Most universities, institutes, and schools in Islamic countries were mixed by the end of the last Hijri century. Educational institutions in Al- Haramin country (Saudi Arabia nowadays) escaped mixing and issued the education policy document in $\left(1390^{\mathrm{h}}\right)$ among which there was article number (155) that stated that, " mixing of boys and girls at all levels of education is forbidden, except in nurseries and kindergartens. Saudi Arabia in this policy that prevents mixing rescued itself from the bad effects of mixing that most countries all over the world, whether Islamic or not, suffer from nowadays.

\section{The most important negative effects of mixing}

1. Committing immorality and doing the disgusting: A study conducted by the National Union for British Teachers emphasized that the co-education has led to the phenomenon of pregnant schoolgirls by adultery though their ages were less than sixteen years old. The study also proved that the rate of sexual crimes through adultery and young girls' abuse has increased largely. In America, for example, the proportion of pregnant schoolgirls through adultery was about (48\%) in one secondary school.

As for the testimonies of some people who witnessed mixing, an article of the famous writer Lady Cook stated that, "mixing is favorable for men. Women have desired it despite the fact that it is against their innate. The number of illegitimate children will increase along with the availability of mixing. Therefore, women should be taught to stay away from men. They should be told about the machination that is waiting them [13].

Co-education has many bad results such as adultery by will or by force followed by pregnancy, then abortion or birth of an illegitimate child. Behavioral deviations for such children will later on cause them to commit crimes and so on till the appearance of a long series of moral and behavioral troubles and security dangers that cost societies a lot.

2. Feminization of men and nihilism of women: When males and females mix at schools and universities, each gender takes some of the qualities of the other. Men feminize and women mannish. This is exactly what was observed by education officials. The Philippine minister of education, Rijkaard Gelodia, declared that he wants to recruit more male teachers to teach male children in order to acquire the qualities of manhood, rather than feminine qualities they gain from their female teachers.

Mixing of male and female students at schools leads to women virilism. A study prepared by the National Union for British Teachers revealed that aggressive behavior increases among girls who were studying in co-educational schools. Feminization of men kills their manhood. Some of them tend to be fragile and fluid more than women in a way that make them look like women. Woman virilism makes her lose her shyness, which is like a fortified fence for her protection. Then she starts to simulate the man in his actions and deeds. As a result, both men and women become homosexual, i.e. a man makes love to a man and so does the woman, which is the reality of many countries where mixing is very common. In addition, feminized men and mannish women are cursed by many saying of Prophet Mohammed (peace be upon him).

3. Low level of intelligence: Al-Sahli [14] mentioned that through a set of research and field studies conducted in West Germany and Britain, it was found that the intelligence level of students in the mixed schools was low. Intelligence level of students at schools that were not mixed was higher. A study by the British National Institution for scientific Research, published in July 8, 2002 and was conducted on (2954) secondary schools in England aimed to study the impact of school size and type (mixed or not mixed) on its academic performance of education. The study found out that male students' performance was better in non- mixed schools. Girls benefitted more of the separation between the two genders regarding their performance development. Through the analysis of the results of the British General Examinations, it was found out that non-mixed schools were the best and highest. In (2001) the top twenty students in the British examinations were from non-mixed schools. Most of the top fifty students were also of these non-mixed schools.

4. The weakness of creativity and limited talent: A study conducted by the Research Institute of Social Psychology in Bonn, Germany revealed that mixed school pupils were not having creative potentials. They were of limited talent and few hobbies. Nevertheless, apparent creative attempts were clear among schoolchildren of the same-gender because of the preoccupation of each gender by the other instead of creativity and innovation.

5. Obstruction of academic excellence: Specialists of educators have noted that mixing of male and female students in schools hinders academic excellence. They, therefore, separated them and distributed them to a number of schools as an experiment. The result of such isolation revealed that boys when separated from girls, had better achievement results in the secondary school general certificate. Actual experience and its results proved that the number of boys who attained high degrees in a non-mixed class increased four times. Another study in Kyle Institute in Germany showed that girls were more attentive and had better grades when separating them from boys at school.

6. Killing the spirit of competition: Dr. Charles Schuster, a German expert in education once mentioned that unifying the gender in schools, i.e. boys in schools for boys and girls in schools for girls, girls' schools lead to strengthening the spirit of competition among students while mixing stops this motive [14] said that after understanding the negative effects of mixing male and female students in schools and universities, we have to address the issue of female teachers teaching male pupils in first and second elementary classes. Most educators, whether men or women, like Ibn Hazm for example in his book "The Ring of the Dove", said that God created men and women from each other, but made a barrier between them. That barrier has a door that includes both compassion and torment. Those who look for compassion, love, pleasure, serenity and confidence can get through by marriage, while those who climb the wall, come through a hole in 
the ceiling or try to steal others' enjoyment will face anxiety, sickness, people's disrespect, remorse. They will also receive torment in the afterlife.

Abu Osama [15] said that Dr. Saleh Bin Abdulla Bin Hamid mentioned that education is a dress that tailored for the stature of the nation. It is consistent with the nation's teachings, literature and objectives for which it lives and dies. Education is neither a process of buy and sell nor a good to be exported or imported. Nations lose more than they win when they depend in their generations' education and curriculum on importing curricula and setting their plans away from their authenticity, principles and history. The American journalist, Hylian Stanbra, while addressing her devastated society said, "go back to your traditions and morals, prevent mixing and tie up the freedom of the girl, go back to Hijab time which is better than pornographic and the shamelessness of Europe and America, and stop the mixing. We, in America, have suffered a lot. The American society has been full of all kinds of pornography and obscenity. Victims of mixing fill the prisons. Mixing in the American and European community is threatening the family and trembling values and ethics". Anaroad, another writer, says, "It is a shame for the English countries to make their daughters examples of vices through the frequent contact and mixing with men. In Britain, Lady Cook, an English writer, warned of the dangers the mixing of women saying," The size of adultery and the numbers of illegitimate children equal the amount of mixing. Teach your daughters to get away from men".

Boshnaq [16] in the Network of Islamic Knights said that mixing damage and dangers could be understood if we realize that about (70\%$90 \%$ ) of working women at different sectors have committed the sin of adultery. Half of those women working in the field of security who were subjected to a referendum indicated that their superiors at work subjected them to committing adultery. Even universities and places of education have not escaped from these vices. A male university professor commits adultery with her female student. Male students, on the other part, do that with their female colleagues or teachers whether by their will or by force.

The researcher in his turn believes that mixing of men and women has not provided anything, just animal sensuality and cattle madness. Committing wicked actions and indecent assault is increasing. This reality refutes the views of all people who claim that mixing breaks lust and styles instinct. Mixing has just increased the glow of lust and increased corruption, like the thirsty drinking from seawater, which just aggravates his thirst [16] asserts this fact. He mentions that about (50\%-70\%) of the American men cheat on their wives and in the same time, about (32\%) of wives cheat on their husbands. In addition, about (90\%) of women got married after losing their virginity. In Britain, the proportion of virgin girls was (0\%). The phenomenon of wife swapping is common there, too. More than two and a half million of the American husbands practiced wife swapping regularly. Moreover, nearly (50\%) of males and females has sexual encounter before the age of fifteen. Wall Street Journal once wrote that out of two Americans one divorced his wife. In the American city, San Mateo, out of the (100) persons who got married at the beginning of the year, (80) persons got divorced at the end of the same year. Furthermore, In the Women's Conference in in Paris, it was found that (70\%) of young French women live lonely. the number of those who are legally married has decreased by $(68,000)$ women. Twenty percent (20\%) of newly born cases were through adultery. In America alone, one and a half million fetuses are killed yearly because of abortion operations.
The researcher, in turn believes that what have been mentioned above are just some of the testimony and convictions of the civilized and urbanized Western people. Thus, it is time for Muslims to stop adopting western ideas and culture via their open media channels, which are directed towards the thoughts of our Muslim nations. It is time for us, as Muslims, to consider what they have realized in order not to go astray and begin asking for help like them. We, Muslims have to understand that the dangers of mixing are more than its benefits.

One most interesting thing is the fact that Western nations have begun working on gender separation in many colleges that reached (100) colleges in USA and high numbers in Europe except public schools. This separation has been after a revision of the problems of mixing like adultery, sexual abnormalities, sodomy, lesbianism, diseases, and a violation of the woman's status and injustice she received from those men who only look at her with lust and mistrust. God, in the Holy Koran, says, "And when you ask prophets's wives for anything, speak to them from behind a curtain, that is cleaner for your hearts and theirs" Sourat Al-Ahzab, verse (53). That is, there should be a barrier between the man and the woman, which indicates forbidding mixing. God also says, "Say to the believers they should lower their gaze and guard their private parts that is purer for them. Allah is Aware of the things they do". Holy Koran, Sourat Al-Nour, verse (50). God also says, "Say to the believing women, that they lower their gaze cast down their eyes and guard their chastity". Holy Koran, Sourat Al-Nour, verse (51). These verses of the Holy Koran clearly order Muslims to lower gaze, which is impossible in the case of mixing. Mohammed, our Prophet, (peace be upon him) also says "A woman is Awrah", i.e. it forbidden to look at her adornment or any part of her body, which proves that mixing is taboo. $\mathrm{He}$, when he saw some women walking in the middle of the street told them to walk aside not in the middle of the street. This incident, once again indicates that mixing is not allowed even in streets. One more example to show that mixing is not allowed is the prophet's saying "none left behind me is more harmful to men than the women's (fitnah) affliction". Therefore, mixing is against this because it means the gathering of men and women in one place. So how can a man and a woman meet in one place?

Some people may use what is happening in the Circumambulation, in the markets, and the exit of women for nursing in the era of the Prophet (peace be upon him) as examples to show that mixing is not taboo. Whe replying to them, it can be said that these are not examples or proofs since there is a clear indication represented in a written text that forbids mixing. In circumambulation, women have to be doing so behind men as Muslim women did in the era of the Prophet (peace be upon him). Men are closer to Kaaba, but what happens nowadays is against the origin. However, circumnavigation in this way, although it is not correct, cannot be compared to what advocates of mixing call for. They go further and advocate for mixing in education and work at all times and places, not only in a specific time as in circumambulation.

With regard to the woman's exit to the markets, we can say that what people do cannot be considered as an evidence on Sharee'a (Islam regulations). The woman's stay at home is the basic principle in Islam. If a woman needs to go out, she should do it while wearing her hijab and only for necessity. Her going out for a need does not indicate that mixing is allowed. Nursing at wars is not another evidence to be taken into consideration. Her exit for nursing was in a specific period for a specific need, too. Men were few and women while committed to their hijab, were to fill the shortage. In addition, they were not real nurses nursing patients, but they were to prepare the medicine. As soon as the number of men increased, women stopped nursing at wars. 


\section{Mixing in education for the young}

Some people are calling for mixing children in schools arguing that it does not hurt or affect them. They claim that female teachers are more experienced in coping with them [17] emphasizes that:

1. Many other steps follow mixing. The matter will be easy because "heavy rain starts by a drop and fire begins by a spark".

2. The idea of mixing in education or other fields between men and women is a Masonic idea whose seeds are colonial to our nation. It is more harmful than the invitation for unveiling publicly, finery and take off hijab.

3. The child begins to grow, bloom and look for knowledge at the age of six, which is a reality and proved by experience. Some children reach the age of maturity at the age of nine. Some may fail at his study and reach the age of twelve while he is at his second or third grade, which is the beginning of adolescence stage.

4. If we consider the statistics that come from countries where mixing is normal, we realize the high proportion of crimes of adultery spread, sodomy among the young, pregnant women including those who are below twelve years old, and the frequent anomalies between the males. Sayyed Qotob in [18] says that through his observations in American society, he found out that the proportion of pregnant young females at one secondary school was about (48\%).

5. One result of co-education is the low level of education and the scientific benefit. Anyone who visits some mixed university branches can see students' results in the exams at the end of the year. Some writers have visited a school in Belgium and noted that all students were girls. When asked about that, the headmistress answered saying, "We have seen the damage of the mixing of children even at primary stage [18]. The US Judge, Lindsey mentions that (45\%) of school girls contaminate their honor before they leave these schools. This percentage rises significantly at high education stages.

\section{Mixing reduces lust}

Abdul Rahim [19] said, "Mixing advocates claim that men and women can reduce the severity of sex drive exciting". The following things can be as a reply to such claim:

1. The issue is quite the contrary. Mixing increases the intensity of sex drive motivation. If a man's mixing with a non-forbidden woman dampens sex drive of both, we will see that this motive declines gradually until it vanishes within husbands after a certain period of being married. Nevertheless, this motive continues to grow as long as it is physically and mentally proper. Some, as [18] indicate that more than (90\%) of non-married women in Europe and America always or sometimes practice adultery.

2. What the advocates of lust tuning believe might be true in some places, though many of the unbridled passions are hard to be decreased. Most people think that addiction to experience undergo during the succession of days may end in accordance to what civility advocates desire. Therefore, what can we call this? Isn't it sexual frigidity? If a man meets a woman and is not stimulated as other men do, if no sexual or physical changes occurs to him when he meets a woman, or if he only seeks a lust that does not affect his drive to positive organic status, can't we say that he is sexually frigid. Isn't frigidity a disease that infected people visit doctors for healing and recovery from its symptoms? How can we make this disease one of the goals that we look for on behalf of frustration venting or libido refinement? [20] said that the severity and power of lust is the way for breed improvement while its coldness is a way to breed weakness and the devastation of its characteristics and traits.

3. John Kichelor, a US psychologist says, "(90\%) of the American women are infected by sexual frigidity and (40\%) of men are infected by infertility. He adds that images of nude girls are the reason for the decline in the Americans' sexual level. Because of mixing in the British society, the woman who left her femininity and has been characterized by the qualities of men is now called the third sex, which violates the human's nature and formation and, in the same time, the woman's function and work".

US President, George Bush administration announced its intention to promote the principle of non-mixing of boys and girls in public schools. An announcement about this project was in the Federal Register, an American official newspaper on 05/08/2002. The White House official said, "Primary and secondary schools that would like to separate boys from girls would receive more funding than those that would choose to keep the mixed system", (http://www.washingtonpost. com/wp-dyn...100144 pf.html). Other experts considered that the project advocated by Bush administration would have positive effects on the educational process. A jurist and specialist in the educational system at the United States confirmed that many of the studies conducted on male and female pupils showed that in some stages of their growth, pupils' academic achievement, in the case of separation, increases. In America, there is an association called the National Association for the Promotion of Non-Mixed Public Education that supports this point of view. A study conducted by one university revealed that students in the non-mixed schools were better achievers than peers in the mixed ones. An elementary school principal carried out an experiment where he separated boys from girls in some classrooms. The result was encouraging, the number of noisy boys decreased. Boys' academic level increased suddenly. Girls stopped trying to attract the boys' attention. Teachers could discuss specific issues with boys without the fear of embarrassing the girls and vice versa.

Many other studies revealed that female girls do better in the academic and sports programs in their feminine surrounding. Their self-confidence become better, too. In the United States, there are only (11) schools that adopt the policy of one gender education, while there are many private schools that follow this system. Some educationists in America have started searching for new ways to improve students' achievement in the last ten years. They began to consider the education of one gender. One female student who was fifteen years old mentioned that she only liked the school of girls. Girls used to be frightened and not relaxed when boys were with them. They felt more relaxed when they were in a surrounding full of girls only. President Kennedy, in 1962 declared that the future of America was in danger because its youth were fluid, irresponsible and dumped in lusts. He added that out of seven young men trying to join the military, six were not fit because lusts had corrupted their physical and psychological fitness. US congressional committee said, in one report, that mixing among young people of both genders was the most important cause of juvenile crime. In one of the annual reports in America, it was mentioned that the number of reported rape cases was (180) cases per day. The number of medical centers to treat the effects of rape was more than (700) centers. the number of teenagers who become pregnant each day because of sexual incest was about (2740). Therefore, correct and explicit evidence from the Holy Koran, the Sunanah of the prophet Mohammed (peace be upon him), and the experience of other nations prove the necessity to prohibit mixing because of its bad consequences. 
Professor Peter Kuznak, a specialist in the history of sexuality in the United States, said that "no one in the White House has ever read Michel Foucault, the French philosopher and the author of, The history of sexuality between (1976-1984). Foucault confessed that the separation of males and females could not extinguish the physical desire. Another American scholar believed that separation of the two genders was always devastating. All this falls within the framework of sexual abstinence, which occupies an important place in sex education programs that are funded by the federal state. However, other experts considered that the approach advocated by Bush administration would be reflected positively on the pupils. Prof. Emilio Viano, a lawyer and a specialist in the educational system in the United States, said that many of the studies conducted with the contribution of students showed that in some stages of their development, boys and girls achieved better when they were not mixed. Some girls might feel inclined to certain boys, which deprives them of developing their social lives. We will also find boys who prefer being separated from girls in order not to be committed to certain behaviors in the presence of these girls. The national society for the encouragement of non- mixed public education asserted this view. It concluded, after a study conducted by Michigan University in some mixed and non-mixed Catholic schools, that boys at non-mixed schools were better in reading, writing, and mathematics. Girls also in the non-mixed schools achieved better than peers in the mixed schools [14].

\section{Mixing and its effect on the marital relationship}

Abu Eid [21], in the Divorce Conference at Sharjah University, said that the issue of mixing is serious and very thorny in our Islamic modern societies. It has many bad and dangerous effects on individuals and society. It leads to the deterioration and collapse of precious morality and the destruction of Islamic values [22] says that mixing is a meeting between men and non-prohibited women where they can communicate with each other via looking, signals or speech. A man's being alone with a non-prohibited woman is forbidden in the Islamic regulations. God says, "And when you ask his wives for anything, speak to them from behind a curtain, that is cleaner for your hearts and theirs", Holy Koran, Sourat Al-Ahzab, verse (53). Mohammed, the prophet (Peace be upon him) said, "Be careful of entering at women". A Muslim asked, "even if this man was a father in law? "The prophet said, "Yes, father in law is death itself". He also said, "You are not allowed to be with any woman without Mahram, a man for whom she is prohibited" [23].

These kinds of text indicate that mixing is illegal in Islam because of its corruption, evils, and misdeeds. When a woman, for instance, goes out to work, she mixes with men and speaks to them. They sit together for about eight hours a day and so familiarity takes place between them during such sessions each day [24] says that mixing is a corruptor. For example, a depressed wife goes to work and there meets a colleague who begins to make fun with her, listens to her, and comforts her. Sessions like this are repeated and each time both get closer to each other. At the end, both divorce their mates and get married [22] argues that mixing in the workplace, drives the women to go there unveiled putting different kinds of make-up. She tries to attract others' attention. This way is, of course harmful and exposes her to indecency mainly by evil men. If she follows them, she will damage her home, displace her family, and betray her husband. While, if she opposes them, she will expose herself to charges, suspicion, and doubts, which affects seriously her own life, husband and children. Therefore, the mixing in such cases is a great corruption, especially when a woman is keen to highlight her natural or artificial beauty, breaks in her walking, and speaks kindly.
Some Western women have started calling to ban mixing because they have realized its disadvantages and consequent results. For, instance, the American journalist, Helsan Stenbera, wrote, “The Arab society is complete and proper. It is worth keeping its traditions that benefit boys and girls in a reasonable range. Arab society is different from the European and American societies as it has inherited ethics that restrict women" [22] advises Muslims to adhere to their traditions and ethics. She calls them to prohibit mixing, restrict the girl's freedom and return to the era of the veil, which is better than the pornography and shamelessness of Europe and America. The American society has become a complex one full of all pornography and obscenity. Victims of mixing and freedom are filling the prisons, sidewalks, and bars. Mixing in the American society is threatening family and trembling values and ethics.

In conclusion, we can say that those who advocate woman's freedom at workplaces and call for her mixing in man's community are seculars who are far from God' laws. They only want to enjoy the women and take her out of her religion, faith, chastity, and purity.

\section{The effect of mixing on the relationship between spouses}

Through what has been mentioned before, the seriousness of mixing can be clearly seen on the relationship between spouses and family stability. To what extent does mixing affect the relationship between spouses? Is there any direct impact of mixing on the number of divorce cases? No field studies that can shed light on the effect of mixing on the relationship between spouses are found. However, we can draw on some studies in other fields. For instance [24] says that mixing with no controls made divorce easier after it was very difficult to happen. It also raises sex instinct and encourages women to show their beauty. Marriage will be useless to give spouses infallibility in a mixed society, i.e. each one will leave the other if he/she finds better enjoyment. The husband might look for a girlfriend and so does the wife. In another article entitled "Mixing", reported by the Library of Islamic awakening on the Internet, it was mentioned that a study conducted in Syria concluded that the first cause for divorce among spouses was their co-work [25] mentioned that the employment of teachers in Iraq was the cause of their divorce. The evolution that has occurred in the status of women lifted the restrictions on their behavior, gave them the opportunity to mix with men in cultural and social fields, provided them with an opportunity to work in various jobs, and allowed them to study the character of the partener, in appropriate circumstances. On the other hand, the woman's work ensures her autonomous and physical independence, which leads to discussions that could be the cause of many problems and consequently her divorce.

There is no doubt that mixing in the workplace is a cause of divorce, for several reasons:

1. Arousing suspicion between the spouses as the husband will not trust his wife of being in contact with someone else.

2. The repeated going out of the woman and mixing with men lead to neglecting her house and husband.

3. The woman's co-work with man creates jealousy in men and women, which can be a cause of divorce [26] showed that divorce rate because of the woman's co-work exceeded (7.4\%).

In brief, mixing in the workplace is one of the main causes of divorce. It leads to different kinds of damage and evils that are not limited to the spouses, but also the family and the whole community. 


\section{Conclusion}

The present study aimed to study the effect of mixing at Sudanese universities on students' social and psychological compatibility. Through the review of many studies, researches and writings of many people, it found out that learners at Sudanese universities often experience many negative effects where the academic atmosphere is mixed. For instance, their success and innovation outcomes were better wherever boys were separated from girls. Their levels of attention and psychological compatibility were also higher when boys were isolated from girls at university. Therefore, stakeholders of education in Sudan are recommended to be careful of these points when deciding to allow mixing at Sudanese universities. They have to understand that:

1. The basic principle of Shareeah (Islamic teachings) is the prevention of mixing in one place, even if it is for a prayer, pilgrimage, or other rites.

2. The family should be responsible for the sound upbringing that persuades the girl and boy of the fact that mixing leads to the destruction of morality.

3. The role of media in the Arab countries should be activated to help in preventing mixing through serials and movies.

4. Governments of Islamic countries should seriously seek to separate boys from girls in schools and universities. They should find buildings for each gender whatever the cost is.

5. Co-education weakens the religious restraint of both genders and leads to the occurrence of evil and distractions because of mixing. It is the cause for the appearance of illegal marriages between men and women, even if they were committed.

6. Education, Science, and Culture Organization (ISESCO) should bear responsibility toward establishing educational programs that call for chastity and virtue and find a special culture for mixing concept.

\section{References}

1. Battah A, Tarawneh K (1999) Problems of Foreign Students at Mutah University, Journal of Yarmouk Research 15: 153-169

2. Wolman BB (1989) Dictionary of Behavior Science, ( $2^{\text {nd }}$ edition $)$, New York.

3. Attouf MY, Abu Howaij M (1983) Psychological Field Studoes in the Arab Environment, Beirut, Lebanon: University House for Printing and Publishing.

4. Suleiman S, Mnaizel A (1999) Compatibility Degree among Students of Sultan Qaboos University and its Relationship to Gender, Academic Semester, and Average, Journal of Educational Sciences, 26: 99-154.
5. Helmi M (1967) Psychological Compatibility O University Female Student and its Relationship to a Set of Variables, Yearbook of Girls' College at Ain Shams University, $5,1-41$.

6. Radwan S (1996) Social Psychology, (5 $5^{\text {th }}$ Edition), Beirut, Lebanon: University Corporation for Studies, Publishing and Distribution.

7. Zahran H (1984) Social Psychology, (5 ${ }^{\text {th }}$ edition), Cairo, Egypt: the World of Books.

8. Al-Zayyadi M (1956) Clinical Psychology, Cairo, Egypt: the Anglo-Egyptian Library.

9. Al-Lail MJ (1993) A Study of some Variables Associated with University Community of King Faisal University Students. Arab Journal of Education 12.

10. Hefny Q (1998) New Researches in Educational Psychology, Cairo, Egypt: Raafa Library.

11. Ismail ME (2002) A Test of Self-Concept of the Old, Cairo, Egypt: Egyptian Renaissance Bookshop.

12. Zidane A (2004) Fatwa about Mixing, Islam Online, Accessed on 14/04/2004.

13. Al-Siba'i M (1999) The Woman between Jurisprudence and Law, ( $6^{\text {th }}$ edition), Beirut, Lebanon: Al-Warraq House for publishing and Distribution.

14. Al-Sahli M (1999) Thus Began Mixing, Islamic Arena.

15. Abu Osama (2002) Mixing: its Dangers and Corruptions, Islamic Nation Network.

16. Boshnaq F (2004) The Hijab (Veil) between the West Hostility and Azhar Secularism, Islamic Network of Knights.

17. Al-Jaw'aan MN (2004) Hey, Advocates of Mixing, Wait a Minute.

18. Qawji WS (2000) Muslim Woman, Al-Qalam House for Printing, Publishing and distribution.

19. Abdul Rahim AS (1992) Factors of Sexual Deviation and Methodology of Islam in its Prevention and Treatment. Amman, Jordan: Al- Nafa'es House for Publishing and Distribution.

20. Abu Khalil S (2004) Islam in the Dock, (5 $5^{\text {th }}$ Edition), Damascus, Syria: Al-Fikr House for publishing.

21. Abu Eid AK (2004) The Woman's Work and Mixing and their Impact on the Divorce Rate Increase, Divorce Conference in Sharjah University in April 2004.

22. Hassan HA (2001) Origins of Muslim Woman Contemporary Education, Beirut, Lebanon: Al-Resalah Foundation.

23. Al-Khin M (1987) Nozhat Al Motaqin: An Explanation of Riyadh Al Saliheen for Nawawi, (4 $4^{\text {th }}$ Edition), Al-Resalah Foundation.

24. Al-Ik KA (1998) Personality of Muslim Woman, (1 ${ }^{\text {st }}$ Edition) Beirut, Lebanon: Knowledge House.

25. Al-Janabi AS (1983) Social and Cultural Variables of the Divorce Phenomenon with a Field Study of the Phenomenon of Divorce in Baghdad, ( $3^{\text {rd }}$ Edition), Baghdad, Iraq: Al- Horiyah House for printing.

26. Al-Harasees K (1996) Problems of Divorce in Jordan and the Woman's Role (Unpublished MA. Thesis), University of Jordan, Jordan.

Copyright: (C2016 Al-Mihaisi MO. This is an open-access article distributed under the terms of the Creative Commons Attribution License, which permits unrestricted use, distribution, and reproduction in any medium, provided the original author and source are credited. 